\title{
Psychometric validation of Corah's Dental Anxiety Scale in the Polish population
}

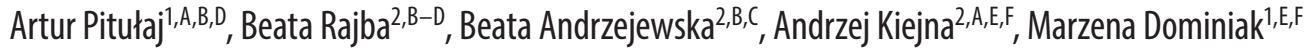 \\ ${ }^{1}$ Dental Surgery Department, Wroclaw Medical University, Poland \\ 2 Psychology Research Unit for Public Health, University of Lower Silesia, Wrocław, Poland \\ A - research concept and design; $B$ - collection and/or assembly of data; $C$ - data analysis and interpretation; \\ $D$ - writing the article; $E$ - critical revision of the article; $F$ - final approval of the article
}

\section{Address for correspondence \\ Artur Pitułaj \\ E-mail: arturpitulaj@gmail.com}

Funding sources

None declared

Conflict of interest

None declared

Received on February 16, 2019

Reviewed on March 31, 2019

Accepted on August 18, 2019

Published online on January 17,2020

\begin{abstract}
Background. Corah's Dental Anxiety Scale (DAS) is one of the most popular psychological scales used for diagnosing odontophobia worldwide. Despite being used by Polish researchers, it has never been validated in the Polish population. Also, there are no similar tools that could be used by dentists for screening.

Objectives. The aim of this study was to validate and present the psychometric properties of the Dental Anxiety Scale adapted to Polish. The scale is a self-assessment tool designed to measure odontophobia and dental anxiety.
\end{abstract}

Material and methods. The sample consisted of 162 adults. The adaptation to Polish of the DAS scale included a back-translation and a think-aloud study. The validation procedure incorporated 3 basic methods to be applied in the reliability analysis - the test-retest method, the statistical properties analysis of test items as well as a factor analysis. The general result of the responders was also compared to the anxiety-trait STAI scale and the neuroticism scale form IPIP-BMF-20.

Results. The Cronbach's a was 0.9. The solution obtained in the exploratory factor analysis was a one-factor model, explaining $76.24 \%$ of the variance of responses. The test-retest gave a strong correlation (rho $=0.69$, $p<0.001)$. The correlations between the DAS score, the anxiety-trait STAI score and the neuroticism scale form IPIP-BMF-20 were moderate, as expected. The percent of responders with odontophobia and intense dental anxiety was almost similar to the results of other studies.

Conclusions. The psychometric characteristics of the Polish adaptation of the DAS scale are similar to those reported in the original version. The results allow us to recommend the method for scientific research and patient screening. However, further analyses are necessary to assess if the scores indicating odontophobia and dental anxiety are similar in Poland and in the USA.

Key words: dental anxiety, odontophobia, psychology

Cite as

Pitułaj A, Rajba B, Andrzejewska B, Kiejna A, Dominiak M.

Psychometric validation of Corah's Dental Anxiety Scale in the Polish population. Adv Clin Exp Med. 2020;29(1):45-49. doi:10.17219/acem/111818

DOI

10.17219/acem/111818

Copyright

Copyright by Author(s)

This is an article distributed under the terms of the

Creative Commons Attribution 3.0 Unported (CC BY 3.0)

(https://creativecommons.org/licenses/by/3.0/) 


\section{Introduction}

The ability to both psychologically and physically adapt to the surrounding, ever-changing world is a prerequisite for the survival of every species. One of the main defense mechanisms against threats is escape, which in the psychological sphere is reflected by the feeling of anxiety and fear. Properly functioning neurological centers of anxiety fulfill the evolutionary protective function and enable the individual to react adequately in order to avoid danger. ${ }^{1}$

Anxiety is defined as an unpleasant emotional state and is a physiological reaction to a stimulus being a potential threat. It accompanies every human being almost from the moment of birth. Fear, on the other hand, is a fully conscious reaction to danger, promoting the cautious behavior of the individual. ${ }^{2}$ Excessive fear may paralyze and interfere with the rational thought processes, and in the long-term it may intensify or become an independent etiological factor of many different somatic diseases, such as cardiovascular disorders or diabetes. ${ }^{3,4}$

A particular type of anxiety disorder is phobia. Its main symptom is the persistent fear of specific situations, phenomena or objects, leading to their avoidance at all costs. The stimuli that induce pathological anxiety reactions are in this case situations or objects that even in the patient's own opinion do not pose a threat, and people affected by the phobia are aware of the irrationality of their feelings. ${ }^{5}$ These anxiety disorders are a significant social problem and have even been included as a disease entity in the International Statistical Classification of Diseases and Related Health Problems ICD-10. ${ }^{6}$

Odontophobia is one of the most common phobic disorders and may affect up to $20 \%$ of the population, but the results depend to a large extent on the questionnaire used. ${ }^{7,8}$ Corah's Dental Anxiety Scale (DAS) usually shows slightly lower results than other psychological tools. Odontophobia is defined as an irrational and difficult to control fear of visiting a dentist, which is often the effect of past experiences, especially from childhood, a time when the physician had no possibility of providing total pain control. This fear is sometimes so strong that despite the existence of disturbing oral complaints associated with negligence in the dentition, patients postpone going to the dentist. ${ }^{9}$

Dental fear consists of 3 components: fear of pain, of injury to the body and of the unknown. Physiological, behavioral and psychological methods are used to assess the anxiety of dental patients. Physiological methods are based on the assessment of measurable and observable reactions of the body to stress stimuli. They include the following: measurement of the blood pressure, heart rate assessment, changes in muscle tone, perspiration, and reduction of salivation. Behavioral methods refer to the use of behavioral scales that use subjective doctor's opinion about changes in the patient's behavior and are mainly used in children. Psychological methods are based on the analysis of special self-assessment questionnaires, elaborated by the psychologists. ${ }^{10}$
One of the most popular psychological tools used to assess the level of dental anxiety is DAS, created by Corah in 1969. It is a simple questionnaire consisting of 4 items, each containing 5 possible answers. Each answer has an assigned numeric value (1-5). The sum of the values assigned for each response is the result of the test and can vary from 4 to 20 points. A score of 17-20 points indicates odontophobia (Table 1).

Table 1. The relationship between the DAS test result and the patient's level of anxiety according to Corah $^{29}$

\begin{tabular}{|l|c|}
\hline \multicolumn{1}{|c|}{ DAS result } & Dental anxiety level \\
\hline$<9$ & low \\
\hline $9-12$ & moderate \\
\hline $13-14$ & high \\
\hline $15-20$ & very high \\
\hline
\end{tabular}

Despite its creation in 1969 and the existence of slight modifications, usually enriching the original test with 1 additional question, it is still one of the most frequent tools used to analyze the level of dental anxiety and is applicable worldwide. ${ }^{11-14}$ In the studies of the Polish population, DAS was used numerous times at the turn of the $20^{\text {th }}$ and $21^{\text {st }}$ centuries, yet it has never been validated, only translated. ${ }^{15-21}$

The aim of this study is to present the psychometric properties of the Polish adaptation of the Corah's DAS. By validation we mean measuring the accuracy and reliability of the method. ${ }^{22}$ In the case of DAS, it was impossible to determine its validity by comparing it with other methods examining the severity of dental anxiety, as it is the first tool of this type in Poland. In order to estimate the accuracy of the scale, it was decided that it should be combined with the anxiety-trait subscale of the State-Trait Anxiety Inventory (STAI) questionnaire, where anxiety is understood as a permanent personality attribute, as well as with the neuroticism subscale from the International Personality Item Pool-Big Five Markers-20 (IPIP-BFM-20) questionnaire based on Big Five personality theory. ${ }^{23-25}$ Both tools have excellent psychometric properties. Neuroticism, as well as its cortical aspect, the tendency to react with fear, ${ }^{26}$ are predictors of anxiety in the situation of a visit to the dentist, although the correlation is weak. ${ }^{27}$ It was assumed that the percentage of people with odontophobia and severe anxiety according to the original scale would help us gauge the accuracy of the Polish adaptation. The reliability of the tool was examined by calculating Cronbach's $\alpha$, as well as using the test-retest method.

\section{Description and psychometric characteristics of the original scale}

The DAS by Norman L. Corah is a simple tool, perfectly suited to screening dental anxiety and odontophobia in dental patients who require special treatment and special attention from their dentist. ${ }^{28,29}$ The questionnaire consists of 4 items describing successively situations related to dental 
treatment: appointment at the dentist the next day, waiting in the dentist's waiting room, waiting on a dental chair for drilling, and finally a rich description of waiting for tooth scraping near the gums during the removal of tartar. For each item, the subject has to respond using a five point scale.

The original validation studies performed on the student population showed that the scale is characterized by a high reliability ratio - Kuder-Richardson coefficient was 0.86 , although due to the fact that the scale is not dichotomous, it would be more appropriate to calculate Cronbach's $\alpha{ }^{30}$ The correlation between the first result and the retest after about 3 months was 0.82 , which indicates a high stability of results over time. In addition, because fear of the dentist is met with considerable understanding and social acceptance, the respondents did not show a tendency to provide insincere answers.

\section{Material and methods}

The language validation procedure was carried out in accordance with the guidelines described in the literature. ${ }^{31}$ Because the author of the DAS scale, N.L. Corah, died in 2001, we first obtained the official written permission of the publisher. Then, the instructions and test items were translated into English, leading to the development of the initial language version of the DAS scale, which was then subjected to the retranslation procedure. The language version created this way has been checked and corrected by experts fluent in English and with expert knowledge - psychologists and linguists. The scale obtained satisfactory results of Gunning's fog index. The 4 items were translated into Polish as follows:

1. If you had to go to the dentist tomorrow, how would you feel about it?

2. When you are waiting in the dentist's office for your turn in the chair, how do you feel?

3. When you are in the dentist's chair waiting while she/he gets her/his drill ready to begin working on your teeth, how do you feel?

4. You are in the dentist's chair to have your teeth cleaned. While you are waiting and the dentist is getting out the instruments which she/he will use to scrape your teeth around the gums, how do you feel?

For the $1^{\text {st }}$ question, the Polish adaptation of the scale of answers looks as follows:

a) I would look forward to it as a reasonably enjoyable experience.

b) I wouldn't care one way or the other.

c) I would be a little uneasy about it.

d) I would be afraid that it would be unpleasant and painful.

e) I would be very frightened of what the dentist might do.

For the remaining 3 test items, the response scale, also 5-level, describes the feelings of a person using dental services: a) relaxed,

b) a little uneasy,

c) tense,

d) anxious,

e) so anxious that I sometimes break out in a sweat or almost feel physically sick.

After considering experts' comments, an experimental version of the scale was created, which was used in a thinkaloud pilot study conducted among 23 psychology students. ${ }^{32}$ These persons informed the investigators how they understand individual test items, and the researchers checked the compatibility of the interpretation with the original meaning of the items. This allowed for the official approval of the Polish language version of the questionnaire and for it to be subjected to a psychometric assessment process.

\section{Results}

One hundred sixty-two students participated in the study of the validation procedure. The specificity and number of participants is similar to the one in the original scale. Both the Bartlett sphericity test $\left(X^{2}=387,738\right.$, degrees of freedom $(\mathrm{df})=6, \mathrm{p}<0.001)$ and the Kaiser-Meyer-Olkin test (0.828) indicate the adequacy of analyzing the matrix for the existence of common factors, and thus mean that the sample number and diversity are adequate. Then, an analysis of the discriminative power of the questionnaire items was carried out. The results are presented in Table 2.

The discriminatory power of the analyzed items is satisfactory - the discrimination factor of all 4 significantly exceeds 0.2 . In order to verify the internal structure, an exploratory factor analysis was carried out, which showed that all the items are loading 1 strong factor, explaining $76.24 \%$ of the responses variance.

In the Polish adaptation of the DAS, the Cronbach's $\alpha$ reliability coefficient was 0.898 , which is a very good result for a scale of only 4 items and shows that it is a reliable tool that can successfully be used for screening the level of dental anxiety. To determine the absolute stability coefficient of the tool, 47 students were examined twice at an interval of 2 months. The correlation of the obtained results was 0.69 ( $\mathrm{p}<0.001)$, which indicates satisfactory stability of the scale over time. To determine the validity of the tool, the results of 32 subjects on the DAS scale were compared with the scale of anxiety as a trait of the STAI questionnaire and with the neuroticism scale of the IPIP-BFM-20 questionnaire. As expected, the result was moderate in both cases - rho $=0.314$ and rho $=0.38$, respectively $(\mathrm{p}<0.05)$.

\section{Discussion}

The aim of the above studies was to create the Polish adaptation of the DAS scale, allowing screening to identify patients with odontophobia and increased anxiety, and 
Table 2. Discrimination rate of test items $(n=162)$

\begin{tabular}{|c|c|c|c|}
\hline Item & $\begin{array}{l}\text { Item-total } \\
\text { correlation }\end{array}$ & M & SD \\
\hline 1. If you had to go to the dentist tomorrow, how would you feel about it? & 0.795 & 2.97 & 1.043 \\
\hline 2. When you are waiting in the dentist's office for your turn in the chair, how do you feel? & 0.845 & 2.41 & 1.092 \\
\hline $\begin{array}{l}\text { 3. When you are in the dentist's chair waiting while she/he gets her/his drill ready to begin } \\
\text { working on your teeth, how do you feel? }\end{array}$ & 0.718 & 2.82 & 1.005 \\
\hline $\begin{array}{l}\text { 4. You are in the dentist's chair to have your teeth cleaned. While you are waiting and } \\
\text { the dentist is getting out the instruments which she/he will use to scrape your teeth around } \\
\text { the gums, how do you feel? }\end{array}$ & 0.691 & 2.48 & 1.018 \\
\hline Total DAS score & & 10.68 & 3.632 \\
\hline
\end{tabular}

M - mean; SD - standard deviation.

to determine its psychometric characteristics. In the sample collected during the validation of the DAS-PL scale, $5.9 \%$ of the responders reached a score of 17 points and higher, allowing for odontophobia diagnosis, and another $18.7 \%$ obtained the result between 15 and 17 points, allowing us to suspect quite intense anxiety. This result is almost similar to the one obtained in the study of the Łódz region population, in which, however, another non-validated method was used..$^{33}$ It is also similar to the results achieved in other studies with the original version of the DAS scale and its adaptations, which is another premise of its validity.

Numerous studies of the level of dental anxiety and odontophobia with the use of tools that have only been translated without a full cultural adaptation and validation procedure indicate the urgent need for such a tool. It will also be useful in the dental practice as a quick and easy screening tool. The use of such scales is recommended as the golden standard for treatment, ${ }^{34}$ and for example in the UK, they are used by about $20 \%$ of dentists, surprisingly men more often than women. ${ }^{35}$

\section{Conclusions}

On the basis of all the analyzed psychometric characteristics, it can be concluded that the Polish adaptation of the DAS scale does not deviate significantly from the original one and that it has good psychometric properties. However, it has not yet been normalized. The adopted values of $15-17$ points for high anxiety and 17-20 points for odontophobia have been established on the basis of American population studies; however, a similar percentage of people with odontophobia and intense anxiety in the Polish sample indicate that they are probably adequate. We can, therefore, recommend using the DAS scale with the awareness of its limitations for screening in dental offices and for scientific research.

\section{ORCID iDs}

Artur Pitułaj (1) https://orcid.org/0000-0002-9025-2628 Beata Rajba (1) https://orcid.org/0000-0002-3945-1568 Beata Andrzejewska (1) https://orcid.org/0000-0003-0526-2408 Andrzej Kiejna (1) https://orcid.org/0000-0002-3708-3853 Marzena Dominiak (1) https://orcid.org/0000-0001-8943-0549

\section{References}

1. LeDoux JE. Evolution of human emotion: A view through fear. Prog Brain Res. 2012;195:431-442.

2. Gruz E, Jaczewski M, Juzala P. Analysis of anxiety level, factors modulating it and the stereotype of dentist in case of patients undergoing dental surgical treatment [in Polish]. Dent Med Probl. 2006;43(300): 415-420.

3. Smith KJ, Béland M, Clyde M, et al. Association of diabetes with anxiety: A systematic review and meta-analysis. J Psychosom Res. 2013; 74(2):89-99.

4. Roest $A$, de Jonge $P$, Lim $C$, et al. Fear and distress disorders as predictors of heart disease: A temporal perspective. J Psychosom Res. 2017;96:67-75.

5. Bilikiewicz A, Pużyński S, Wciórka J, Rybakowski J. Psychiatria. Vol. 2. Wrocław, Poland: Urban \& Partner; 2003.

6. ICD-10. Vrozdział. Klasyfikacja zaburzeń psychicznych izaburzeńzachowania w ICD. Opisy kliniczne i wskazówki diagnostyczne. Warszawa, Poland: Uniwersyteckie Wydawnictwo Medyczne „Vesalius”; 2000.

7. Amila Z, Jasmin H, Edina H, Muhamed A, Elmedin B. Evaluation of dental fear and anxiety in displaced persons in Bosnia and Herzegovina. Acta Stomatol Croat. 2018;52(2):140-147.

8. Mahdi RIA, Aljabry AS. Attitude and practice of dentists towards management of dental fear and anxiety in public dental hospitals in Sudan. IOSR-JDMS. 2017;16(8):51-60.

9. KaczmarekU,Grzesiak I, Kowalczyk-Zając M, Bader-Orłowska D. The level of dental anxiety and the dental status in 18-year-olds [in Polish]. Czas Stomatol. 2008;61:81-87.

10. Kaczmarek U, Kanaffa-Kilijańska U, Frydecka D. Methods of evaluation of dental anxiety in children and adolescents [in Polish]. Dent Med Probl. 2010;47(1):97-100.

11. Coolidge T, Konstantinos NA, Dimitris E, et al. Psychometric properties of Greek versions of Modified Corah Dental Anxiety Scale (MDAS) and the Dental Fear Survey (DFS). BMC Oral Health. 2008;8:29.

12. Yuan S, Freeman R, Lahti S, et al. Some psychometric properties of the Chinese version of the Modified Dental Anxiety Scale with cross validation. Health Qual Life Outcomes. 2008;6:22.

13. Javadinejad S, Farajzadegan Z, Madahain M. Iranian version of a face version of the Modified Child Dental Anxiety Scale: Transcultural adaptation and reliability analysis. J Res Med Sci. 2011;16(7):872-877.

14. Bahammam MA, Hassan MH. Validity and reliability of an Arabic version of the modified dental anxiety scale in Saudi adults. Saudi Med J. 2014;35(11):1384-1389.

15. Olszewska I, Żarow M, Gofrom B., Paczyńska P. Analiza stopnia lęku pacjentów przed leczeniem stomatologicznym. Magazyn Stomat. 2000;10(7-8):58-62.

16. Kobierska A, Sobaniec H, Gołębiewska M, Józefowicz W. Lęk przed leczeniem stomatologicznym - analiza w aspekcie płci, wieku i środowiska badanych. Prot Stomat. 1995;45:341-350.

17. Kobierska A. Stres w gabinecie stomatologicznym. Czas Stomat. 1995; 43:526-531.

18. Kobierska A. Lęk przed leczeniem stomatologicznym - analiza związku ze stanem uzębienia. Prot Stomat. 1996;46:229-232.

19. Sporniak-Tutak K. Ocena lęku u pacjentów przed zabiegami stomatologicznymi. Czas Stomat. 1995;48:396-400. 
20. Kamprowska B, Sokalski J. Psychologiczne uwarunkowania reakcji pacjenta na zabiegi w gabinecie stomatologicznym. Poz Stomat. 1999;26:127-131.

21. Kalinowski T. Poziom lęku pacjentów podejmujących leczenie stomatologiczne. Magazyn Stomat. 2001;11(5):52-59.

22. Brzeziński J. Metodologia badań psychologicznych. Warszawa, Poland: PWN; 2012.

23. Spielberger ChD, Gorusach, Lushene RE, The State-Trait Anxiety Inventory (STAI) Test Manual for Form X. Palo Alto, CA: Consulting Psychologists Press; 1970.

24. Wrześniewski K, Matusik D, Sosnowski T. Inwentarz stanu i cechy lęku STAI: polska adaptacja STAI: podręcznik. Warszawa, Poland: Pracownia Testów Psychologicznych Polskiego Towarzystwa Psychologicznego; 2002.

25. Skimina E, Strus W, Topolewska E, Rowiński T, Cieciuch J. The short IPIP-BFM-20 questionnaire for measuring the Big Five. Annals of Psychology. 2014;17(2):285-402.

26. Eysenck MW, Byrne A. Anxiety and susceptibility to distraction. Pers Individ Dif. 1992;13(7):793-798.

27. Jumana K, Mahmoud K, Khaled Q, Firas AM. Personality and oral health. J Contemp Dent Pract. 2009;10(6):1-16.
28. Corah NL. Development of a dental anxiety scale. J Dent Res. 1969; 48(4):596.

29. Corah NL, Gale EN, Illig SJ. Assessment of a dental anxiety scale. J Am Dent Assoc. 1978;97(5):816-819.

30. Hornowska E. Testy psychologiczne: teoria i praktyka. Warszawa, Poland: Scholar, 2007.

31. Beaton DE, Bombardier C, Guillemin F, Ferraz MB. Guidelines for the process of cross-cultural adaptation of self-report measures. Spine (Phila Pa 1976). 2000;25(24):3186-3191.

32. Van Someren MW, Barnard YF, Sandberg JA. The Think Aloud Method: A Practical Guide to Modelling Cognitive Processes. London, UK: Academic Press; 1994.

33. Sopińska K, Olszewska N, Bołtacz-Rzepkowska E. The effect of dental anxiety on the dental status of adult patients in the Lodz region [in Polish]. Dent Med Probl. 2017;26(1):73-78.

34. Falco $E$, Manani G, Zanette $G$. The relevance of hypnosis and behavioural techniques in dentistry. Contemp Hypn Integr Ther. 2013;29(4): 332-351.

35. Dailey YM, Humphris GM, Lennon MA. The use of dental anxiety questionnaires: A survey of a group of UK dental practitioners. Br Dent J. 2001;190(8):450-453. 